\title{
CORRELATION OF ROUTINELY GIVEN YOGA EXERCISE WITH LEVEL OF ANXIETY IN ELDERLY OF YUSWO WIDODO INTEGRATED SERVICE POST SURABAYA

\author{
${ }^{1)}$ Felicia Margareth ${ }^{2)}$ Gladdy S Waworuntu ${ }^{3)}$ Willy F Maramis
}

\begin{abstract}
Introduction: The percentage proportion of older people in Indonesia is increasing, indicating that Indonesia is a country with a population structure leaning towards the elderly. If one does not die before that, every human being will surely experience an aging process that can cause various problems such as health problems. Anxiety is one of the serious health problems in the elderly. Physical exercise, such as yoga, can help reduce anxiety level.

Aim: To analyze correlation between yoga exercise and level of anxiety in the elderly in Posyandu Lansia Yuswo Widodo Surabaya.

Method: This research used a pre-experimental study with pre-posttest one group design, held on the 26th of July 2019 until the 16th of September 2019. The samples in this study were 22 people, all of whom were elderlies who routinely visited and have participated in 16x yoga exercise for two months. The research instrument this study used was HARS. Kendall's Tau B was used for the data analysis.

Results: data analysis shows that there was a correlation between routine yoga exercise and the level of anxiety in the elderly in Posyandu Lansia Yuswo Widodo Surabaya $p=0,030$. Pretest results showed that there were 14 elderly with mild anxiety and eight elderly with moderate anxiety. post-test data showed five elderly with mild anxiety levels and 17 people who did not have anxiety.

Conclusion: There was a correlation between the routine of yoga exercise and the level of anxiety in the elderly in Posyandu Lansia Yuswo Widodo Surabaya.
\end{abstract}

Keyword: Yoga routine exercise, decrease level of anxiety, elderly

1) Student of Faculty of Medicine, Widya Mandala Catholic University of Surabaya, Jl. Kalisari Selatan No. 1 Surabaya. Email : feliciamargaret@gmail.com

2) Parasitology Department, Faculty of Medicine, Widya Mandala Catholic University of Surabaya, J1. Kalisari Selatan No. 1 Surabaya

3) Geriatric Department, Faculty of Medicine, Widya Mandala Catholic University of Surabaya, J1. Kalisari Selatan No. 1 Surabaya 


\section{INTRODUCTION}

According to the World Health Organization (WHO), in 2016, anxiety disorders affected $3.8 \%$ of the world's elderly population. ${ }^{1}$ The Ministry of Health's Basic Health Research (Riskesdas) data for 2018 showed that the prevalence of mentalemotional disorders aimed at the emergence of several depressive symptoms and anxiety nationally is $9.8 \%$ in Indonesia's population. This result shows an increase from $6 \%$ in 2013 to $9.8 \%$ in 2018. Mental health problems such as anxiety, stress, insomnia, and depression are among the reasons individuals get either pharmacological, nonpharmacological therapy, or both. ${ }^{2}$ Pharmacological therapy can be given in the form of anti-anxiety that will suppress anxiety symptoms without dealing with the cause of anxiety directly. Nonpharmacological or non-drugs therapy that can be given is yoga exercises. Yoga consistently provides encouraging results in treatment for overall anxiety disorders and panic disorders, and effective in improving mood, reducing symptoms of depression and anxiety in adults and the elderly. ${ }^{3}$ Physical activity has a strong effect on improving mood. The study says that yoga can be as effective as antidepressants in relieving mental conditions without giving side effects $4,5,6$

Yoga affects the parasympathetic and sympathetic nerve activity. Pranayama (breathing) technique of yoga exercises allows the elderly to regulate breathing, then dhyana (meditation) technique will have a calming effect, while physical movement will increase the levels of GammaAminobutyric Acid (GABA); regulate the Pituitary Adrenal Hypothalamus (HPA Axis) which provides anxiolytic effects and reduces sympathetic activation. ${ }^{7}$ This research examined whether there is a correlation between yoga exercises with anxiety levels or not in the elderly of Lansia Yuswo Widodo Integrated Service Post Surabaya to determine the correlation between yoga exercises and anxiety levels.

\section{METHOD}

The study design was pre-experimental with pre-test-post-test one group design conducted at Lansia Yuswo Widodo Integrated Services Post Surabaya, Bratang Gede VI D No. 2, Ngagelrejo, Wonokromo District, Surabaya City, and East Java. The time of the study was July 26 to September 16, 2019. The number of respondents obtained was 55 people with data collection techniques using probability sampling with the results of respondents after the inclusion and exclusion of 22 people. The variables studied were the level of anxiety in the elderly. data was collected by interviewing and distributing questionnaires. Data were processed and analyzed with Kendall's Tau B test using the SPSS system. 


\section{RESULTS}

Table 1 Result Study

\begin{tabular}{|c|c|c|}
\hline Sex & $\begin{array}{l}\text { Frequency } \\
\text { (n) }\end{array}$ & $\begin{array}{l}\text { Percentage } \\
(\%)\end{array}$ \\
\hline Male & 0 & 0 \\
\hline Female & 22 & 100 \\
\hline \multicolumn{3}{|l|}{ Age } \\
\hline 55 Years old & 2 & 9.1 \\
\hline 56 Years old & 3 & 13.6 \\
\hline 57 Years old & 2 & 9.1 \\
\hline 58 Years old & 1 & 4.5 \\
\hline 59 Years old & 2 & 9.1 \\
\hline 60 Years old & 3 & 13.6 \\
\hline 61 Years old & 2 & 9.1 \\
\hline 62 Years old & 1 & 4.5 \\
\hline 63 Years old & 2 & 9.1 \\
\hline 64 Years old & 3 & 13.6 \\
\hline 65 Years old & 1 & 4.5 \\
\hline \multicolumn{3}{|l|}{$\begin{array}{l}\text { Educational } \\
\text { Level }\end{array}$} \\
\hline Do not school & 1 & 4.5 \\
\hline $\begin{array}{l}\text { Primary } \\
\text { school }\end{array}$ & 7 & 31.8 \\
\hline $\begin{array}{l}\text { Junior high } \\
\text { school }\end{array}$ & 7 & 31.8 \\
\hline $\begin{array}{l}\text { Senior high } \\
\text { school }\end{array}$ & 6 & 27.3 \\
\hline Diploma & 0 & 0 \\
\hline Bachelor & 1 & 4.5 \\
\hline \multicolumn{3}{|l|}{$\begin{array}{l}\text { Decrease of } \\
\text { Anxiety Level }\end{array}$} \\
\hline Decrease & 22 & 100 \\
\hline Stagnant & 0 & 0 \\
\hline
\end{tabular}

Based on Table 1, it was found that the respondents consisted of 22 female (100\%) with the majority age of respondents was 56 years old (13.6\%) and 60 years old (13.6\%). Data obtained from respondents who participated in the study based on their level of education mostly came from the elementary school group (31.8\%), which amounted to seven respondents, and the junior high school group (31.8\%) .

\section{Table 2 Pre-Test and Post-Test Data}

\begin{tabular}{llll}
\hline $\begin{array}{l}\text { Pre- } \\
\text { Test } \\
\text { Scor } \\
\text { e }\end{array}$ & $\begin{array}{l}\text { Anxiety } \\
\text { Level }\end{array}$ & $\begin{array}{l}\text { Frequenc } \\
\text { y (n) }\end{array}$ & $\begin{array}{l}\text { Percentag } \\
\text { e (\%) }\end{array}$ \\
\hline$<14$ & $\begin{array}{l}\text { Not } \\
\text { present }\end{array}$ & 0 & 0 \\
$14-$ & Mild & 14 & 63.6 \\
20 & & 8 & 36.4 \\
$21-$ & Moderate & 8 & \\
27 & & & \\
\hline $\begin{array}{l}\text { Post- } \\
\text { Test } \\
\text { Scor }\end{array}$ & & & \\
e & & & 77.3 \\
$<14$ & Unworrie & 17 & 22.7 \\
$14-$ & d & 5 & 0 \\
20 & Mild & 5 & \\
$21-$ & Moderate & 0 & \\
27 & Mod & \\
\hline
\end{tabular}

In table 2 there were no respondents $(0 \%)$ with pre-test scores below $14(<14)$, however. In contrast, after yoga exercise ; 17 respondents $(77.3 \%)$ had a score below 14 , which was the unworried category. The pretest score between 14 and 20, which is the category of Mild anxiety, had 14 respondents (63.6\%), and scores between 21 and 27, which is the Moderate anxiety category had eight respondents $(36.4 \%)$. In the post-test score, there were no results in the Moderate anxiety category. 
Table 3 Anxiety Level Before and After Study

\begin{tabular}{|c|c|c|}
\hline $\begin{array}{l}\text { Anxiety } \\
\text { Level before } \\
\text { study }\end{array}$ & $\begin{array}{l}\text { Frequency } \\
\text { (n) }\end{array}$ & $\begin{array}{l}\text { Percentage } \\
(\%)\end{array}$ \\
\hline Unworried & 0 & 0 \\
\hline Mild & 14 & 63.6 \\
\hline Moderate & 8 & 36.4 \\
\hline $\begin{array}{l}\text { Anxiety } \\
\text { Level after } \\
\text { study }\end{array}$ & & \\
\hline $\begin{array}{l}\text { Mild become } \\
\text { moderate }\end{array}$ & 0 & 0 \\
\hline $\begin{array}{l}\text { Mild become } \\
\text { unworried }\end{array}$ & 14 & 63.6 \\
\hline $\begin{array}{l}\text { Moderate } \\
\text { become mild }\end{array}$ & 5 & 22.7 \\
\hline $\begin{array}{l}\text { Moderate } \\
\text { become } \\
\text { unworried }\end{array}$ & 3 & 13.6 \\
\hline
\end{tabular}

Table 3 discussed the level of anxiety based on HARS scores obtained before and after the study. Mild anxiety obtained before the study as many as 14 people (63.6\%) who after yoga interventions all became less anxious . Subjects with moderate anxiety before the study as many as eight people (36.4\%), after intervention was divided into two levels, namely mild anxiety by five people $(22.7 \%)$ and becoming unworried as many as three people (13.6\%).
Table 4 Correlation Analysis Between Anxiety Level Before and After Study doing Yoga Exercise in the Elderly

\begin{tabular}{|c|c|c|c|c|c|c|}
\hline & $\mathrm{n}$ & $\begin{array}{l}\text { Mea } \\
\mathrm{n}+ \\
\mathrm{SD}^{-}\end{array}$ & $\begin{array}{l}\text { Ma } \\
\mathrm{x}\end{array}$ & $\begin{array}{l}\mathrm{Mi} \\
\mathrm{n}\end{array}$ & $\begin{array}{l}\text { Mean } \\
\text { Differen } \\
\text { ce }\end{array}$ & $\mathrm{p}$ \\
\hline $\begin{array}{l}\text { Pre- } \\
\text { test } \\
\text { HAR } \\
\text { S }\end{array}$ & $\begin{array}{l}2 \\
2\end{array}$ & $\begin{array}{l}19,2 \\
2+ \\
4,43\end{array}$ & 27 & 14 & $-9,68$ & $\begin{array}{l}0,03 \\
0\end{array}$ \\
\hline $\begin{array}{l}\text { Post- } \\
\text { test } \\
\text { HAR } \\
\text { S }\end{array}$ & $\begin{array}{l}2 \\
2\end{array}$ & $\begin{array}{l}9,54 \\
+\quad \\
4,90\end{array}$ & 18 & 2 & & \\
\hline
\end{tabular}

Based on Table 4, the analysis result showed that there was a significant correlation between the provision of routine yoga exercise and the decrease of anxiety level in the elderly using Kendall's Tau B Test with $p=0,030$ or $p<0,05$.

\section{DISCUSSION}

\section{Characteristics of Respondents}

This study chose respondents with age ranges from 55 to 65 years old. The choice of age from 55 to 65 years old was due to the consideration of yoga exercises that are riskier if respondents were aged over 65 years; hence, with this consideration, it was decided to limit the age of respondents to 65 years old. 
Twenty-two respondents who participated in this study consisted of older women; this is in accordance to a study conducted by Heningsih from Kusuma Husada College of Health Sciences with the title Overview of Anxiety Rates for the Elderly the Wredha Dharma Bhakti Kasih Surakarta Nursing Home in 2014. The study results stated that anxiety often occurs in elderly female sex due to hormonal changes that have occurred with a decrease in estrogenic levels, menopause has occurred, and the condition of losing a partner can be a cause of anxiety the elderly. ${ }^{8}$

Results of Routine Yoga Exercise on the Anxiety Level in the Elderly

Based on the results of Kendall's Tau B analysis test in this study, it was found that the value of $p=0.030$ where the value of $p$ can be said to be significant if $p<0.05$, hence, it was found that there is a significant correlation between the provision of routine yoga exercises to the level of anxiety in the elderly of Lansia Yuswo Widodo Integrated Service Post Surabaya in this study. The correlation between routine yoga exercises and the anxiety level in the elderly can be explained by several theories, among which are theories that explain that yoga exercises can trigger the secretion of Gamma Amino Butyric Acid (GABA). The primary function of GABA is reducing arousal, aggression and anxiety. Yoga exercises are conducted to balance the autonomic nervous system that causes physical disorders such as symptoms of cold sweat, fast heart beating, unable to sleep, excessive fear, and others that have a relationship with stress. A yoga breathing technique called pranayama triggers an increase in the activities of the parasympathetic nerves, stimulates the release of oxytocin, and provides a relaxing effect. In the hypothalamus, the hormone oxytocin is produced by magnocellular neurosecretory cells found in the supraoptic and the paraventricular nucleus. Increasing the hormone oxytocin can trigger antianxiety effects and reduce the production of the hormone cortisol. oxytocin concentration in the blood increases due to yoga exercise, thus, the anxiolytic effect of reducing anxiety becomes maximal. It also increases endorphin production, which also decreases anxiety. ${ }^{9}$ The theory can explain the results of this study: the application of yoga exercises to elderly respondents who experienced anxiety resulted in a decrease in the HARS score on questions about feelings of anxiety, fear, tension, autonomic symptoms, and physical symptoms post-test score. $^{10,11,12,13}$

\section{CONCLUSION}

This study shows there is a correlation between the provisions of routine yoga exercises to the anxiety level in the elderly at Lansia Yuswo Widodo Integrated Service Post Surabaya. 


\section{REFERENCES}

1. World Health Organization. Mental Health and Older Adults (Internet). WHO. 2016. Dikutip 2019 Mar 25 dari: https://www.who.int/news-room/factsheets/detail/mental-health-of-olderadults

2. Kemenkes. Hasil Utama Riskesdas 2018 (Internet). Kementerian Kesehatan Republik Indonesia. 2018. (dikutip 2019 Mar 24). Dikutip dari : http://www.depkes.go.id/resources/down load/info-

terkini/materi rakorpop 2018/Hasil\%20 Riskesdas\%202018.pdf

3. Kabat-Zinn J, Massion AO, Kristeller J, Peterson LG, Fletcher KE, Pbert L, et al. Effectiveness of a meditation-based stress reduction program in the treatment of anxiety disorders. Am J Psychiatry. 1992;149:936-43.

4. Jorm AF, Griffiths KM, Christensen H, Parslow RA, Rogers B. Actions taken to cope with depression at different levels of severity: A community survey. Psychol Med. 2004;34:293-9.

5. Saper RB, Eisenberg DM, Davis RB, Culpepper L, Phillips RS. Prevalence and patterns of adult yoga use in the United States: Results of a national survey. Altern Ther Health Med. 2004;10:44-9

6. Unützer J, Klap R, Sturm R, Young AS, Marmon T, Shatkin J, et al. Mental disorders and the use of alternative medicine: Results from a national survey. Am

Psychiatry. 2000;157:1851-7.

7. Ross A, Thomas S. The health benefits of yoga and exercise: a review of comparison studies. J Altern Complement Med [Internet]. 2010Jan;16(1):3-12. Available from: http://www.ncbi.nlm.nih.gov/pubmed/20 105062.

8. Heningsih. Gambaran Tingkat Ansietas pada Lansia di Panti Wredha Dharma Bhakti Kasih Surakarta. Sekolah Tinggi Ilmu Kesehatan Kusuma Husada. 2014
9. Yulinda Y, Purwaningsih D, Sudarta CM. Latihan Yoga Dapat Menurunkan Tingkat Kecemasan pada Siklus Mentruasi Remaja Puteri. J Ners dan Kebidanan Indonesia. 2017;5(1):20.

10. Freitas DA, Holloway EA, Bruno SS, Chaves GS, Fregonezi GA, Mendonça KP. Breathing exercises for adults with asthma. Cochrane Database Syst Rev. 2013;1:CD001277.

11. Cohen L, Warneke C, Fouladi RT, Rodriguez MA, Chaoul-Reich A. Psychological adjustment and sleep quality in a randomized trial of the effects of a Tibetan yoga intervention in patients with lymphoma. Cancer. 2004;100:2253-60.

12. Shaffer HJ, LaSalvia TA, Stein JP. Comparing Hatha yoga with dynamic group psychotherapy for enhancing methadone maintenance treatment: A randomized clinical trial. Altern Ther Health Med. 1997;3:57-66.

13. Brandon H Hidaka. B.A. Depression as a disease of modernity: explanations for increasing prevalence. J Affect Disord. 2012;140:205-14. 